\title{
IMPLEMENTASI PROGRAM PRONA BAGI MASYARAKAT EKONOMI LEMAH
}

\author{
Musleh Herry \\ Fakultas Syariah UIN Maulana Malik Ibrahim Malang \\ email:el.moehy77@gmail.com
}

\begin{abstract}
Abstrak
The importance of land certificate as legal protection for land owners invites the attention of policy makers in this country. The policy which is issued by the government is to issue mass certifying program on land based on the Decree of Ministry of internal affair Number 189 year 1981 On Agrarian National Operation Project (PRONA) implementing by National Defence Board as its duty. Basically, the program is implemented annually through some steps and processes, preparation, coordination/determination of Land Rights, right registration, certificate issuance and delivery of certificates. Obstacles which are faced by the District Land Office or City in implementing the program are in particular aspects such as society as the member of the program, the staff and financial aspect of the program itself.

Pentingnya sertifikat hak atas tanah sebagai perlindungan hukum bagi pemilik tanah mengundang perhatian para pemilik kebijakan di negeri ini. Kebijakan yang di keluarkan pemerintah salah satunya dengan mengeluarkan program pensertipikatan tanah secara massal berdasarkan Keputusan Menteri Dalam Negeri Nomor 189 Tahun 1981 tentang Proyek Operasi Nasional Agraria (PRONA) yang pelaksananya Badan Pertanahan Nasional sebagaimana tugasnya. Pada dasarnya pelaksanaan Program Prona dilakukan secara rutin tiap tahun melalui tahapan atau proses, persiapan, koordinasi/penetapan peserta PRONA, penyuluhan, pengukuran, pengumpulan data, pengumuman, penetapan Hak Atas Tanah, pembukuan hak, penerbitan sertipikat, dan penyerahan sertifikat. Kendala-Kendala yang dihadapi oleh Kantor Pertanahan kabupaten atau Kota dalam mengimplementasikan program PRONA adalah terjadi dibeberapa aspek yaitu: aspek masyarakat peserta PRONA, aspek petugas dan aspek keuangan pembiayaan program PRONA.
\end{abstract}

Kata Kunci : Implementasi, Program Prona, Masyarakat Ekonomi Lemah

Dalam Pasal 1 ayat (3) Undang-Undang Dasar Negara Republik Indonesia Tahun 1945 (UUD 1945) secara tegas dinyatakan bahwa Negara Indonesia berdasarkan atas hukum (Rechtsstaat), tidak berdasarkan kekuasaan belaka (Machststaat). Negara hukum salah satu prinsipnya yaitu adanya jaminan kepastian hukum, ketertiban hukum dan perlindungan hukum, yang berisi nilai-nilai kebenaran dan keadilan, dengan memberikan jaminan serta perlindungan atas hak-hak warga negara. Sebagai ketentuan Undang-Undang Dasar, maka apa yang tercantum dalam UUD 1945 ini, disamping mempunyai kedudukan yuridis yang sangat tinggi, mendasar, juga mempunyai nilai filosofis dan nilai politis dalam kehidupan berbangsa dan bernegara. Segala kebijakan para penyelenggara negara di bidang ekonomi dan pertanahan termasuk segala cabang produksi dan pengelolaan bumi, air dan seluruh 
kekayaan alam yang terkandung di dalamnya tidak boleh menyimpang dari ketentuan UUD 1945.

Indonesia merupakan negara agraris, yang sebagian besar masyarakatnya menggantungkan hidupnya pada bidang pertanian, sehingga tanah memegang peranan sangat penting bagi kehidupan manusia, yang berfungsi sebagai sumber daya produksi maupun sebagai wadah untuk memenuhi kebutuhannya, seperti halnya mendirikan rumah, gedung perkantoran, sektor pertanian, perkebunan, perindustrian, pembangunan jalan, jembatan, prasarana rekreasi, pendidikan, peribadatan, instansi pemerintah dan lain sebagainya. Dengan demikian tanah memegang peranan yang sangat strategis dalam berbagai sektor kehidupan manusia, seperti dalam aspek ekonomi, politik dan hukum. ${ }^{1}$ Ketiga aspek tersebut merupakan isu sentral yang saling berkaitan sebagai satu kesatuan yang terintegrasi dalam pengambilan proses kebijakan hukum pertanahan yang dilakukan oleh pemerintah dan juga untuk menjamin kepastian hukum.

Pemberianjaminankepastianhukum dibidang pertanahan, pertama-pertama memerlukan tersedianya perangkat hukum tertulis, lengkap dan jelas, yang dilaksanakan secara konsisten sesuai jiwa dan isi ketentuan-ketentuannya. Selain itu dalam menghadapi kasus-kasus konkrit diperlukan pula terselenggaranya pendaftaran tanah, yang memungkinkan bagi para pemegang hak atas tanah agar dapat dengan mudah membuktikan hak atas tanah yang dikuasainya. Oleh karena pemerintah telah menetapkan UUPA sebagai landasan hukum yang dalam pelaksanaannya diatur lebih lanjut melalui Peraturan Pemerintah Nomor 24 Tahun 1997 tentang Pendaftaran Tanah, yang mulai berlaku sejak tanggal 8 Oktober 1997.

Setelah berlakunya UUPA, ketentuan pendaftaran tanah diatur dalam Pasal 19 UUPA. Untuk menjamin kepastian hukum oleh pemerintah dilakukan pendaftaran tanah di seluruh wilayah Negara Republik Indonesia

${ }^{1}$ Idham, Konsolidasi Tanah Perkotaan Dalam Perspektif Otonomi Daerah, (Bandung: Alumni, 2004), h. 1. menurut ketentuan-ketentuan yang diatur dengan peraturan pemerintah. Pertama, pendaftaran tersebut dalam ayat (1) pasal ini meliputi: (a) Pengukuran, pemetaan, dan pembukuan tanah; (b) Pendaftaran hak-hak atas tanah dan peralihan hak-hak tersebut; (c) Pemberian surat-surat tanda bukti hak, yang berlaku sebagai alat pembuktian yang kuat. Kedua, pendaftaran tanah diselenggarakan dengan mengingat keadaan negara dan masyarakat, keperluan lalu lintas sosial ekonomi serta kemungkinan penyelenggaraannya, menurut pertimbangan Menteri Agraria. Ketiga, dalam peraturan pemerintah diatur biaya-biaya yang bersangkutan dengan pendaftaran tersebut ayat (1) di atas, dengan ketentuan bahwa rakyat yang tidak mampu dibebaskan dari pembayaran biaya-biaya tersebut.

Apa yang telah diperintahkan oleh Pasal 19 ayat (1) UUPA tersebut, kemudian ditegaskan lebih lanjut dalam Pasal 3 Peraturan Pemerintah R.I. Nomor 24 Tahun 1997 tentang Pendaftaran Tanah, yang tujuannya adalah: (1) Untuk memberikan kepastian hukum dan perlindungan hukum kepada pemegang hak atas suatu bidang tanah, satuan rumah susun, dan hak-hak lain yang terdaftar agar dengan mudah dapat membuktikan dirinya sebagai pemegang hak yang bersangkutan; (2) Untuk menyediakan informasi kepada pihak-pihak yang berkepentingan termasuk pemerintah agar dengan mudah dapat memperoleh data yang diperlukan dalam mengadakan perbuatan hukum mengenai bidang-bidang tanah dan satuan-satuan rumah susun yang sudah terdaftar; (3) Untuk terselenggaranya tertib administrasi pertanahan.

Kedua peraturan perundang-undangan di atas merupakan bentuk pelaksanaan pendaftaran hak atas tanah dalam rangka Recht Kadaster, yang bertujuan memberikan kepastian hukum dan perlindungan hukum kepada pemegang hak atas tanah, dengan alat bukti berupa buku tanah dan sertipikat tanah. Selanjutnya dalam melaksanakan proses penyelenggaraan tertib hukum pertanahan tersebut dilaksanakan oleh organisasi pelaksana lembaga pemerintahan non departemen yaitu Badan Pertanahan 
Nasional/ BPN. BPN dibentuk berdasarkan Keputusan Presiden Nomor 26 Tahun 1988 tentang Badan Pertanahan Nasional. ${ }^{2}$ Pembentukan BPN dilatar belakangi oleh adanya kebutuhan, penguasaan dan penggunaan tanah pada umumnya termasuk kepentingan pembangunan yang dirasakan semakin tinggi sehingga dikhawatirkan akan menimbulkan peningkatan permasalahan yang timbul di bidang pertanahan.

Berdasarkan Pasal 2 Keputusan Presiden Nomor 26 Tahun 1988, tugas Badan Pertanahan Nasional adalah untuk mengelola dan mengembangkan administrasi pertanahan, yang meliputi: (a) Pengaturan penggunaan, pengurusan dan pemilikan tanah; (b) Pengurusan hak-hak tanah; (c) Pengukuran dan Pendaftaran Tanah; (d) Dan lain-lain yang berkaitan dengan masalah pertanahan. Pentingnya perlindungan hukum bagi pemilik tanah mengundang perhatian para pemilik kebijakan di negeri ini. Kebijakan yang dikeluarkan pemerintah salah satunya dengan mengeluarkan program pensertifikasian tanah secara massal salah satunya adalah program pensertifikasian tanah berdasarkan Keputusan Menteri Dalam Negeri Nomor 189 Tahun 1981 tentang Proyek Operasi Nasional Agraria (PRONA) yang pelaksanaannya Badan Pertanahan Nasional sebagaimana tugasnya.

Di samping ditetapkan dalam Keputusan Menteri Dalam Negeri Nomor 189 Tahun 1981, Proyek Operasi Nasional Agraria (PRONA) juga dijadikan sebagai salah satu program dalam Rencana Strategis BPN RI 2007-2009 untuk meningkatkan program penguatan hak atas tanah rakyat yang dimuat dalam Peraturan Kepala Badan Pertanahan Nasional Republik Indonesia Nomor 6 Tahun 2006. ${ }^{3}$ Rencana Strategis BPN RI 2007-2009 dimaksudkan agar tugas dan fungsi yang dimandatkan kepada BPN RI dapat diwujudkan dan Agenda Kebijakan dapat dilaksanakan untuk mencapai sasaran ${ }^{2}$ Sekarang dirubah menjadi Peraturan Presiden Republik Indonesia Nomor 10 Tahun 2006 tentang Badan Pertanahan Nasional.

${ }^{3}$ Peraturan Kepala Badan Pertanahan Nasional Republik Indonesia Nomor 6 Tahun 2006 tentang Rencana Strategis Badan Pertanahan Nasional Republik Indonesia (Renstra BPN-RI) Tahun 2007-2009. strategis yang diinginkan, maka dirumuskan strategi yang salah satu strateginya adalah meningkatkan Program Penguatan Hak atas Tanah Rakyat melalui akselerasi program PRONA. ${ }^{4}$

Rencana Strategis BPN-RI Tahun 20072009 merupakan wadah harmonisasi perencanaan, serta pelaksanaan tugas dan fungsi pemerintah di bidang pertanahan pasca penataan kembali organisasi BPN RI secara menyeluruh, terintegrasi, efisien dan sinergis dengan berbagai sektor dalam rangka mencapai tujuan pembangunan nasional. ${ }^{5}$

Ditetapkannya Proyek Operasi Nasional Agraria (PRONA) dalam Restra BPN RI 2007-2009 atas dasar Peraturan Kepala Badan Pertanahan Nasional Republik Indonesia Nomor 6 Tahun 2006 dan dalam Keputusan Menteri Dalam Negeri Nomor 189 Tahun 1981 tentang Proyek Operasi Nasional Agraria (PRONA) menunjukkan akan urgennya tujuan program ini dalam mengatasi persoalan-persoalan di bidang pertanahan terutama di bidang akselerasi pengutan hak atas tanah rakyat untuk menjamin kepastian hak atas tanah tersebut secara hukum dan perlindungannya.

Di pertengahan tahun 2011 ini, maka Proyek Operasi Nasional Agraria (PRONA) sudah mencapai 30 tahun dalam perjalanannya dan dalam Restra sudah mencapai 4 tahun perjalanan, di usia yang sudah sedemikian rupa ini, maka bagaimana sesungguhnya lika-liku perjalanan program ini pada dataran implementasinya di lapangan tepatnya di kantor-kantor BPN di seluruh Indonesia yang memiliki tugas dalam hal tersebut.

\section{Dasar Hukum Pelaksanaan Program Prona Di Indonesia}

Bagi bangsa Indonesia, tanah merupakan unsur vital dalam kehidupan berbangsa dan bernegara. Hubungan bangsa Indonesia dengan tanah adalah hubungan yang bersifat abadi. Seluruh wilayah Negara Kesatuan Republik

${ }^{4}$ Buku 1 Rencana Strategis BPN-RI Tahun 20072009, h. 12

${ }^{5}$ Buku 1 Rencana Strategis BPN-RI Tahun 20072009, h. 12 
Indonesia (NKRI) merupakan kesatuan tanah air dari keseluruhan Bangsa Indonesia. Tanah merupakan perekat NKRI. Oleh karena itu tanah perlu dikelola dan diatur secara nasional untuk menjaga keberlanjutan sistem kehidupan berbangsa dan bernegara. Dalam kerangka ini, amanat konstitusi menegaskan agar politik dan kebijakan pertanahan diarahkan untuk mewujudkan tanah untuk "sebesar-besar kemakmuran rakyat".

Meskipun telah diamanatkan dalam UUD 1945 bahwa tanah merupakan sumber kemakmuran rakyat, namun jumlah rakyat miskin Indonesia masih cukup besar (sekitar 39 juta jiwa). Hal ini terjadi karena masih terjadi ketimpangan struktur penguasaan, pemilikan, penggunaan, dan pemanfaatan tanah (P4T). Ketimpangan P4T dan ketimpangan terhadap sumber-sumber produksi lainnya menyebabkan semakin sukarnya upaya penurunan kemiskinan dan pengangguran. Ketimpangan P4T juga dapat mendorong terjadinya kerusakan sumberdaya tanah dan lingkungan hidup, peningkatanjumlah sengketa, konflik dan perkara pertanahan. Lebih lanjut, permasalahan pertanahan ini akan berdampak terhadap rapuhnya ketahanan pangan yang pada akhirnya akan berpengaruh terhadap ketahanan nasional.

Dalam rangka menjalankan amanat konstitusi tersebut dan menyelesaikan berbagai persoalan pertanahan yang ada, maka perlu dirumuskan strategi dan kebijakan pertanahan nasional yang secara fundamental mampu menciptakan struktur sosial dan tatanan politik nasional yang lebih kokoh. Hal ini dituangkan dalam Rencana Strategis BPN RI Tahun 2007-2009yang merupakan wadah harmonisasi perencanaan, serta pelaksanaan tugas dan fungsi pemerintah di bidang pertanahan pasca penataan kembali organisasi BPN-RI secara menyeluruh, terintegrasi, efisien dan sinergis dengan berbagai sektor dalam rangka mencapai tujuan pembangunan nasional.

Salah satu program Rencana Strategis BPN-RI Tahun 2007-2009 tersebut adalah penguatan hak atas tanah rakyat melalui program akselerasi PRONA. Pensertifikasian tanah secara masal melalui PRONA merupakan salah satu kegiatan pembangunan pertanahan yang mendapat tanggapan positif dari masyarakat. Selama ini pelaksanaan kegiatan pendaftaran tanah dalam 5 dekade, yang dimulai pada tahun 1961 baru mampu melaksanakan pendaftaran tanah sebanyak \pm 34 juta bidang dari \pm 85 juta bidang. ${ }^{6}$

Pasal 19 Undang-Undang Nomor 5 Tahun 1960 tentang Peraturan Dasar Pokok-pokok Agraria (UUPA) menetapkan bahwa untuk menjamin kepastian hukum oleh Pemerintah diadakan pendaftaran tanah di seluruh wilayah Republik Indonesia. Sehubungan dengan hal tersebut Badan Pertanahan Nasional Republik Indonesia (BPN RI) yang berdasarkan Peraturan Presiden Nomor 10 Tahun 2006 tentang Badan Pertanahan Nasional, ditugaskan untuk melaksanakan urusan pemerintahan di bidang pertanahan, antara lain melanjutkan penyelenggaraan percepatan pendaftaran tanah sesuai dengan amanat Pasal 19 UUPA tersebut, terutama bagi masyarakat golongan ekonomi lemah sampai menengah melalui kegiatan PRONA yang sudah dilaksanakan sejak tahun 1981.

Percepatan pendaftaran tanah diselenggarakan hendaknya memperhatikan prinsip bahwa tanah secara nyata dapat meningkatkan kesejahteraan masyarakat, berperan secara jelas untuk terciptanya tatanan kehidupan bersama yang lebih berkeadilan, menjamin keberlanjutan kehidupan masyarakat, berbangsa dan bernegara untuk meminimalkan perkara, masalah, sengketa dan konflik pertanahan.

Disamping itu, percepatan pendaftaran tanah juga merupakan pelaksanaan dari 11 Agenda BPN RI, khususnya untuk meningkatkan pelayanan pelaksanaan pendaftaran tanah secara menyeluruh, dan penguatan hakhak rakyat atas tanah. Sejalan dengan itu, untuk menentukan arah dan kebijakan bagi pendaftaran tanah ke depan, berdasarkan Peraturan Kepala Badan Pertanahan Nasional Republik Indonesia (BPN-RI) Nomor 6 Tahun 2006 telah ditetapkan Rencana Strategis

${ }^{6}$ Data lansiran BPN RI Tahun 2010. www.bpn.go.id, diakses tanggal 10 Juli 2011 
BPN-RI Tahun 2007-2009. Agar dicapai hasil yang optimal maka perlu disusun Petunjuk Teknis (Juknis) sebagai pelaksanaan lapangan kegiatan Program Nasional Agraria (PRONA) sebagaimana telah diuraikan di atas.

PRONA adalah kebijakan nasional dibidang pertanahan yang bermaksud untuk memberikan jaminan kepastian hukum bagi pemegang hak atas tanah dalam rangka meningkatkan maupun menunjang pelaksanaan land reform dan menyelesaikan sengketa-sengketa secara tuntas dengan biaya yang murah. Selain itu untuk memberdayakan organisasi dan SDM. Kebijaksanaan ini dimaksudkan agar setiap masyarakat golongan ekonomi lemah dapat memiliki sertipikat hak atas tanah dengan biaya lebih murah, dalam rangka untuk memberikan jaminan kepastian hukum kepada para pemegang hak atas tanah.

Tujuan diadakannya program pendaftaran tanah oleh pemerintah ini adalah dimaksudkan agar pemerintah dengan mudah dapat melakukan pengawasan terhadap pendaftaran tanah. Dengan pendaftaran tanah tersebut diharapkan tidak ada lagi, atau paling tidak dapat mengurangi sengketa pertanahan, misalnya sengketa status dan sengketa perbatasan. ${ }^{7}$

Pada dasarnya PRONA merupakan proyek pensertifikatan tanah secara massal yang memperoleh dukungan dana atau subsidi dari pemerintah melalui Anggaran Pendapatan dan Belanja Negara (APBN) yang dibebankan kepada Badan Pertanahan Nasional. ${ }^{8}$ Pensertifikatan tanah melalui PRONA ini memberikan banyak keuntungan dibanding dengan penyertifikatan yang dilakukan atas keinginan sendiri. Keuntungan tersebut, antara lain adanya subsidi dari pemerintah, sehingga pemohon sertifikat mendapatkan keringanan biaya dan cepatnya proses penerbitan sertifikat sesuai dengan waktu yang telah ditetapkan. ${ }^{9}$

Proses penerbitan sertifikat, melalui PRONA pada dasarnya sama dengan penerbitan sertifikat atas kehendak sendiri. Perbedaannya,

\footnotetext{
${ }^{7}$ Wawancara dengan Ahmad Bedda, Ketua Seksi Konflik dan Sengketa Tanah Kantor Pertanahan Kabupaten dan Kota, Batu Tanggal 5 Juli 2011.

${ }^{8}$ Wawancara dengan Ahmad Bedda.

${ }^{9}$ Wawancara dengan Ahmad Bedda.
}

jika permohonan sertifikat melalui PRONA, pemohon datang ke kantor kepala desa yang mengkoordinir untuk menyerahkan data-data fisik tanahnya sehingga tidak harus datang ke kantor Pertanahan. Sedangkan permohonan sertifikat kehendak sendiri, selain harus datang langsung ke kantor pertanahan, pemohon juga harus membayar biaya yang lebih mahal. ${ }^{10}$

BPN Kabupaten dan Kota sebagai salah BPN yang ada di Negara ini yang juga memiliki tugas dan fungsi sebagaimana telah dikonsepkan dalam PKBPN Nomor 4 Tahun 2006 tanggal 16 Mei 2007 tentang Organisasi dan Tata Kerja Kantor Wilayah Badan Pertanahan dan Kantor Pertanahan, pada dasarnya telah mengimplementasikan program PRONA yang telah diputusakan dalam Keputusan Menteri Dalam Negeri Nomor 189 Tahun 1981 Tentang Proyek Operasi Nasional Agraria, dan ditetapkan dalam Peraturan Kepala Badan Pertanahan Nasional Republik Indonesia Nomor 6 Tahun 2006 tentang Rencana Strategis Badan Pertanahan Nasional Republik Indonesia (Renstra BPN RI) Tahun 2007-2009.

Dalam mengimplementasikan penguatan hak atas tanah rakyat melalui akselerasi program PRONA di Badan Pertanahan Kabupaten dan Kota, secara teoritis dapat dilakukan melalui beberapa tahapan, yaitu: ${ }^{11}$

\section{Tahapan persiapan}

Tahap persiapan dimulai dengan penetapan lokasi PRONA. Acuan yang digunakan untuk melakukan penetapan lokasi PRONA adalah berdasarkan kriteria desa yang dikeluarkan BPS Kabupaten dan Kota. Untuk Kabupaten dan Kota sendiri terdapat 4 kriteria, yaitu terdiri dari kartu biru, hijau, kuning dan merah. Adapun Kecamatan yang ditetapkan sebagai lokasi PRONA adalah Kecamatan Junrejo yang dispesifikkan pada Desa Beji, Desa Tlekung, dan Desa Pendem.

\section{Koordinasi/ Penetapan Peserta PRONA}

Tahap kedua adalah penetapan peserta PRONA. Penetapan peserta PRONA dapat

\footnotetext{
${ }^{10}$ Wawancara dengan Ahmad Bedda.

${ }^{11}$ Wawancara dengan Ahmad Bedda.
} 
dilakukan dengan cara: (1) Diusulkan dari desa melalui Kepala Desa (untuk golongan ekonomi lemah sampai menengah); (2) Ditetapkan dengan SK oleh Kepala Kantor BPN Kabupaten dan Kota. Sasaran PRONA di wilayah kerja Kantor Pertanahan Kabupaten dan Kota adalah meliputi seluruh peserta PRONA. Akan tetapi yang diutamakan diantara para peserta tersebut adalah peseta pemilik tanah dari masyarakat ekonomi lemah-menengah dengan memenuhi kriteria: ${ }^{12}$ (i) Pemilik tanah berada di lokasi PRONA; (ii) Pemilik tanah tersebut berpenghasilan kurang dari/sama dengan gaji UMR; (iii) Nadzir yang mengelola tanah waqaf untuk tujuan dan kepentingan keagamaan/ sosial; (iv) Anggota organisasi seperti: Perintis Kemerdekaan, Angkatan 45, Legiun Peteran, Bepapri, Warkauri, Wredatama, ABRI, dan Pensiunan PNS; (v) Pemilik tanah yang bertempat tinggal di kecamatan letak tanah objek PRONA untuk tanah pertanian.

\section{Penyuluhan}

Penyuluhan PRONA Badan Pertanahan Nasional (BPN) Kabupaten dan Kota dilakukan untuk memberikan penjelasan program, tujuan serta manfaat, persyaratan permohonan hak, subjek dan objek kegiatan PRONA, hak dan kewajiban peserta PRONA yang sesuai dengan perundang-undangan yang berlaku. Penyuluhan PRONA juga diteruskan dengan mensosialisasikan kepada masyarakat desa calon peserta program Prona dengan penyebaran brosur yang berisi informasi mengenai PRONA. Tujuan penyuluhan adalah untuk memberitahukan kepada pemilik tanah/kuasanya/pihak lain yang berkepentingan bahwa di Desa/Kelurahan akan diselenggarakan kegiatan PRONA. Dengan penyeluhan ini, maka tidak ada lagi masyarakat yang tidak mengetahui bahwa di daerahnya akan dilaksanakan program PRONA.

\section{Pengukuran}

Pengukuran tanah dilakukan oleh seksi survei pengukuran dan pemetaan Kantor Pertanahan Kabupaten dan Kota. Sebelum pengukuran dilakukan, para pemilik tanah dianjurkan agar

\footnotetext{
${ }^{12}$ Wawancara dengan Ahmad Bedda.
}

memasang tanda batas terhadap tanah yang dimiliki. Pengukuran tersebut telah disaksikan dan disetujui oleh para tetangga yang tanahnya berbatasan dengan tanah pemilik (bentuk berita acara pemasangan tanda batas). Setelah tanah diukur oleh juru ukur, maka untuk memenuhi asas contradicteur de limitatie, maka para pemilik tanah yang berbatasan langsung dengan tanah yang diukur wajib membubuhi tanda tangannya pada gambar ukur ( GU ) yang dibuat oleh juru ukur.

Produk yang digunakan dalam pengukuran tanah di lokasi PRONA adalah berupa peta bidang yang diberi Nomor Induk Bidang (NIB) untuk masing-masing objek. Peta bidang tersebut kemudian disalin kedalam surat ukur. Seksi Survei Pengukuran dan Pemetaan Kantor Pertanahan Kabupaten dan Kota merupakan pihak yang bertanggungjawab dalam proses penerbitan Surat Ukur dalam program PRONA. Surat Ukur dalam program PRONA diterbitkan setelah data yuridis atas tanah beserta hasil pengukuran oleh Juru Ukur telah.

\section{Pengumpulan Data}

Pengumpulan data dilakukan oleh petugas yang berada di Kantor Pertanahan Kabupaten atau Kota yang telah ditetapkan oleh SK Kepala kantor. Tugasnya adalah menerima permohonan hak yang dilampiri alasan berupa surat tanah, bukti perolehan tanah, izin rekomendasi, dan meneliti berkas perlengkapan tanah. Disamping pengumpulan data, pemeriksaan tanah juga perlu dilakukan setelah berkas-berkas lengkap, kemudian berkas tersebut didaftarkan di loket penerimaan dan selanjutnya diserahkan ke tim panitia pemeriksaan tanah A. Tujuan dilakukannya pemeriksaan tanah adalah untuk meneliti kebenaran dan kesesuaian antara data administrasi (surat-surat kelengkapan berkas permohonan) dengan data fisik (kondisi nyata bidang tanah yang dimohon pemohon di lapangan) serta hubungan hukum antara pemohon dengan tanah.

Sidang pemeriksaan tanah dilakukan oleh panitia A yang sebelumnya telah mengadakan sidang untuk memeriksa dan mengkaji hasil 
pemeriksaan tanah yang dihadiri oleh seluruh panitia A juga pejabat desa/ kelurahan. Hasil sidang tersebut dituangkan kedalam risalah panitia A/ Daftar isi 201. Tugas utama panitia A, adalah: (1) Memeriksa/ mencocokkan data yuridis dan data fisik tanah; (2) Mencocokkan / menguji kebenaran formal surat-surat yang dilampirkan; (3) Memeriksa apakah ada sengketa atau tidak. Bila dalam proses pemeriksaan tanah, Panitia A menemukan ada ketidakcocokkan antara data yuridis dan data fisik, terdapat ketidakcocokkan secara formal surat-surat yang dilampirkan atau terdapat indikasi sengketa, maka Panitia A akan mengembalikan berkas bersangkutan pada pemohon untuk dilengkapi terlebih dahulu.

Apabila pemohon dalam proses telah meninggal dunia sebelum melengkapi berkas yang dikirim Panitia A maka bukti pemilikan tanah yang bersangkutan dapat dilanjutkan oleh para ahli waris pemohon setelah dilakukan proses balik nama. Sedangkan apabila dalam proses penyempurnaan tersebut tanah yang menjadi obyek PRONA telah dijual/ dialihkan oleh pemilik tanah, maka pemilik tanah yang baru dapat melengkapi berkas yang diminta Panitia A dengan melampirkan bukti peralihan hak atas tanah. Setelah berkas permohonan lengkap diperiksa oleh Panitia A, apabila tidak ditemukan ada kekurangan atau ketidak cocokkan secara formil, maka Panitia A membuat dan menandatangani Risalah Pemeriksaan Tanah Panitia A.

\section{Pengumuman}

Kepala Seksi Hak Atas Tanah akan mengumumkan tanah-tanah yang berkasnya telah lengkap, meliputi: (1) Nama pemilik tanah; (2) Nomor Induk Bidang, dan (3) Luas tanah hasil pengukuran. Tujuan diadakannya pengumuman adalah untuk memberikan kesempatan kepada pihak-pihak yang berkepentingan untuk mengajukan keberatan atau sanggahan terhadap data fisik (berupa bidang tanah pemohon) dan data yuridis (orang dan bukti perolehan tanah) dalam rangka untuk penetapan hak atas nama pemohon/ peserta PRONA. Pengumuman meliputi peta bidang tanah dan data luas tanah masing-masing bidang dan data kepemilikan tanah. Waktu pengumuman yang diberikan oleh Badan Pertanahan Nasional (BPN) Kabupaten dan Kota adalah 60 hari kalender atau dua (2) bulan. Apabila keberatan diajukan setelah masa pengumuman berakhir maka keberatan tidak akan ditanggapi oleh Kantor Pertanahan Kabupaten dan Kota.

Selain oleh pemilik tanah, keberatan dapat disampaikan oleh pihak keluarga atau pihak lainnya yang merasa keberatan atas informasi yang disampaikan oleh Kantor Pertanahan Kabupaten dan Kota dengan dilengkapi bukti sah atas keberatan yang disampaikan karena keberatan yang tidak beralasan sah tidak akan ditanggapi dan tidak akan ditindaklanjuti oleh Kantor Pertanahan Kabupaten dan Kota. Dalam hal keberatan yang diajukan oleh pemilik tanah atau pihak lainnya terbukti kebenarannya, tindakan yang dapat dilakukan oleh Kantor Pertanahan Kabupaten dan Kota: (1) Terhadap kekeliruan atas ukuran tanah, maka akan dilakukan pengukuran ulang oleh Juru Ukur Kantor Pertanahan Kabupaten Karanganyar; (2) Terhadap kekeliruan penulisan nama atau identitas pemilik tanah, maka wajib disertakan nama pemilik yang benar yang dikeluarkan oleh Kepala Desa setempat.

\section{Penetapan Hak Atas Tanah}

Penetapan hak atas tanah dilakukan untuk: (1) Bagi tanah milik adat yang memiliki surat lengkap dan memenuhi persyaratan, maka penetapan hak atas tanahnya dilakukan melalui proses konversi; (2) Bagi tanah milik adat yang tidak memiliki bukti, syarat-syaratnya tidak lengkap/meragukan, maka penetapan hak atas tanahnya dilakukan melalui pengakuan hak. Dalam proses Keputusan Pemberian Hak Atas Tanah, pihak yang bertanggung jawab adalah Kepala Kantor Pertanahan Kabupaten dan Kota serta Kepala Seksi Hak Atas Tanah. Setelah Risalah Pemeriksaan Tanah Panitia A dikirim ke Kepala Kantor Pertanahan Kabupaten dan Kota dan setelah tidak ada keberatan yang disampaikan sehubungan dengan tanah-tanah 
tersebut maka Risalah ditanda tangani oleh Kepala Kantor Pertanahan Kabupaten dan Kota dan Kepala Seksi Hak Atas Tanah. Dengan ditanda tanganinya Risalah Panitia A oleh Kepala Kantor Pertanahan Kabupaten atau Kota, maka proses selanjutnya adalah Pembuatan Sertifikat atas nama pemilik tanah.

\section{Pembukuan Hak}

Hak atas tanah dan tanah waqaf didaftarkan dengan membukukan kedalam buku tanah yang di dalamnya memuat data yuridis dan data fisik tanah yang bersangkutan. Jika dalam pembukuan hak terdapat surat ukur, maka surat ukurnya dicatat pula dalam surat ukur tersebut yang disertai dengan pembukuan buku tanah. Surat pencacatan surat ukur merupakan bukti bahwa hak yang bersangkutan beserta pemegang hak dan bidang tanahnya yang diuraikan dalam surat ukur yang secara hukum telah didaftrakan menurut Peraturan Pemerintah Nomor 24 Tahun 2007 Pasal 29 ayat 2.

\section{Penerbitan Sertifikat}

Risalah Panitia A yang telah ditanda tangani oleh Kepala Kantor Pertanahan Kabupaten atau Kota bersama-sama dengan berkas data fisik dan data yuridis yang telah dilengkapi oleh pemohon di daftarkan melalui Kepala Sub Seksi Pendaftaran Hak dan Informasi. Buku tanah (yang memuat data yuridis) dan surat ukur (yang memuat data fisik) yang kemudian dijadikan satu, buku tersebut dinamakan sertipikat. Sertipikat tersebut telah ditandatangani oleh Kepala Kantor Pertanahan Kabupaten atau Kota.

\section{Penyerahan Sertifikat}

BagiSertipikat tanahyangsudah ditandatangani oleh Kepala Kantor Pertanahan Kabupaten atau Kota kemudian diserahkan kepada pemegang hak tanah/kuasanya. Penyerahan tersebut dilaksanakan oleh Kepala Kantor Pertanahan yang berkoordinir dengan pemerintah Desa/ Kelurahan tempat lokasi tanah. Pencatatan sertipikat PRONA dituangkan ke dalam berita acara serah terima sertipikat.

\section{Batasan}

Batasan luas tanah yang ada di Badan Pertanahan Nasiona (BPN) Kabupaten atau Kota terdiri dari: (1) Untuk non-pertanian (perumahan) $=1.000 \mathrm{M}$; (2) Untuk pertanian $=2$ Hektar

Itulah beberapa tahapan implementatif program PRONA di BPN Kabupaten atau Kota, namun pertanyaannya adalah, apakah tahapan-tahapan implementasi yang harus dilalui tersebut berjalan sesuai dengan yang diharapkan? Untuk menjawabnya, maka perlu disajikan realisasi dari kegiatan pelaksanaan program PRONA itu sendiri. Yaitu dengan menentukan daerah yang ditetap sebagai lokus PRONA di wilayah kerja BPN Kabupaten atau Kota. Hal tersebut di atas tentu diharapkan sesuai dengan oreintasi dari program PRONA yang dikhususkan bagi kalang masyarakat ekonomi lemah.

\section{Pendaftaran Hak Atas Tanah.}

Pendaftaran Hak Milik Atas Tanah diatur oleh Peraturan Pemerintah Nomor 24. Tahun 1997 tentang Pendaftaran Tanah, yang ditetapkan dan diundangkan pada tanggal 8 Juli 1997. ${ }^{13}$ Peraturan Pemerintah tersebut kemudian ditindaklanjuti dengan berlakunya Peraturan Menteri Negara Agraria/ Kepala Badan Pertanahan Nasional (BPN) Nomor 3 Tahun 1997, yang mulai berlaku tanggal 8 Oktober 1997. ${ }^{14}$

Berdasarkan Pasal 1 Peraturan Pemerintah Nomor 24 Tahun 1997, yang dimaksud pendaftaran tanah adalah rangkaian kegiatan yang dilakukan oleh pemerintah secara terus menerus, berkesinambungan dan teratur, meliputi pengumpulan, pengolahan, pembukuan, dan penyajian serta pemeliharaan data fisik dan data yuridis, dalam bentuk peta dan daftar, mengenai bidang-bidang tanah dan satuansatuan rumah susun, termasuk pemberian sertifikat sebagai tanda bukti hak bagi bidang-

\footnotetext{
${ }^{13}$ Peraturan Pemerintah Nomor 24. Tahun 1997 tentang Pendaftaran Tanah

${ }^{14}$ Peraturan Menteri Negara Agraria/ Kepala Badan Pertanahan Nasional Nomor 3 Tahun 1997 Tentang Ketentuan Pelaksanaan Peraturan Pemerintah Nomor 24 tahun 1997 Tentang Pendaftaran Tanah
} 
bidang tanah yang sudah ada haknya dan Hak Milik Atas Satuan Rumah Susun serta hak-hak tertentu yang membebaninya. ${ }^{15}$

Menurut Pasal 2 Peraturan Pemerintah Nomor 24 Tahun 1997, pendaftaran tanah dilaksanakan berdasarkan asas-asas: sederhana, aman, terjangkau, mutakhir, dan terbuka. ${ }^{16}$ Adapun tujuan dari pendaftaran tanah diuraikan dalam Pasal 3 Peraturan Pemerintah Nomor. 24 Tahun 1997, yaitu: ${ }^{17}$ (1) Untuk memberikan kepastian hukum dan perlindungan hukum kepada pemegang hak atas suatu bidang tanah, satuan rumah susun dan hak-hak lain yang terdaftar, agar pemilik hak yang bersangkutan dapat membuktikan dirinya sebagai pemegang hak atas tanah tersebut; (2) Untuk menyediakan informasi kepada pihak-pihak yang berkepentingan, termasuk Pemerintah, agar dengan mudah dapat memperoleh data yang diperlukan dalam mengadakan perbuatan hukum mengenai bidang-bidang tanah dan satuan-satuan rumah susun yang sudah terdaftar; (3) Untuk terselenggaranya tertib administrasi pertanahan.

Pelaksanaan pendaftaran tanah meliputi kegiatan: (1) Pendaftaran Tanah untuk pertama kalinya (Initial Registration), yaitu kegiatan yang dilakukan terhadap obyek pendaftaran tanah yang belum didaftar berdasarkan Peraturan Pemerintah Nomor 10 Tahun 1961 dan Peraturan Pemerintah Nomor 24 Tahun 1997; (2) Pemeliharaan Data Pendaftaran Tanah (Maintenance), yaitu upaya penyesuaian data fisik dan data yuridis dalam peta pendaftaran, daftar tanah, daftar nama, surat ukur, buku tanah dan sertifikat dengan perubahan-perubahan yang terjadi kemudian. Sedangkan yang menjadi obyek pendaftaran tanah adalah: (1) Bidangbidang tanah yang dipunyai dengan Hak Milik, Hak Guna Usaha, Hak Guna Bangunan dan Hak Pakai; (2) Tanah Hak Pengelolaan; (3) Tanah wakaf; (4) Hak Milik Atas Satuan Rumah Susun; (5) Hak Tanggungan; dan (6) Tanah Negara.

\footnotetext{
${ }^{15}$ Pasal 1 Peraturan Pemerintah Nomor 24. Tahun 1997 tentang Pendaftaran Tanah

${ }^{16}$ Pasal 1 Peraturan Pemerintah Nomor 24. Tahun 1997 tentang Pendaftaran Tanah, Pasal 2

${ }^{17}$ Pasal 1 Peraturan Pemerintah Nomor 24. Tahun 1997 tentang Pendaftaran Tanah, Pasal 3
}

Sistem pendaftaran tanah mempermasalahkan: apa yang didaftar, bentuk penyimpanan dan penyajian data yuridisnya serta bentuk tanda bukti haknya. Dikenal ada 2 (dua) macam sistem pendaftaran tanah ${ }^{18}$ yaitu: (1) Sistem Pendaftaran Akta (Registration of deeds). Akta merupakan sumber data yuridis, karena aktalah yang didaftar oleh Pejabat Pendaftaran Tanah (PPT), Pejabat Pendaftaran Tanah (PPT) bersifat pasif karena ia tidak melakukan pengujian atas kebenaran data yang disebut dalam akta yang didaftarkan; (2) Sistem Pendaftaran Hak (Registration of Titles). Sistem pendaftaran hak adalah hak yang diciptakan serta perubahanperubahan yang terjadi kemudian dan Pejabat Pendaftaran Tanah (PPT) bersifat aktif karena Pejabat Pendaftaran Tanah (PPT) harus melakukan pengujian kebenaran data yang dimuat dalam akta yang didaftarkan.

Sistem pendaftaran yang dipergunakan dalam Peraturan Dasar Pokok-Pokok Agraria (UUPA) adalah sistem pendaftaran hak (Registration of Titles). Hal tersebut jelas terlihat dengan adanya buku tanah sebagai dokumen yang memuat data yuridis dan data fisik yang dihimpun dan disajikan serta diterbitkannya sertifikat sebagai surat tanda bukti hak yang di daftar. ${ }^{19}$ Sedangkan sistem publikasi diperlukan dalam penyelenggaraan pendaftaran tanah, di mana sistem publikasi dipergunakan untuk menjawab permasalahan ${ }^{20}$ Sejauh mana orang boleh mempercayai kebenaran data yang disajikan tersebut, sejauh manakah hukum melindungi kepentingan kepentingan orangyang melakukan perbuatan hukum mengenai tanah yang haknya sudah didaftar, berdasarkan data yang disajikan di Kantor Pejabat Pendaftaran Tanah (PPT) atau yang tercantum dalam surat tanda bukti hak yang diterbitkan atau didaftar oleh PPT, jika kemudian ternyata data tersebut tidak benar?

Ada beberapa Sistem publikasi tanah yang di anut oleh beberapa Negara yang

\footnotetext{
${ }^{18}$ Boedi Harsono, Hukum Agraria Indonesia-Sejarah Pembentukan, h. 76

${ }^{19}$ Boedi Harsono, Hukum Agraria Indonesia-Sejarah Pembentukan, h. 480

${ }^{20}$ Boedi Harsono, Hukum Agraria Indonesia-Sejarah Pembentukan, h. 80.
} 
menyelenggarakan pendaftaran tanah, yaitu: Pertama, sistem Publikasi Positif. Menurut sistem publikasi positif, suatu sertifikat tanah yang diberikan adalah berlaku sebagai tanda bukti hak atas tanah yang mutlak serta merupakan satu-satunya tanda bukti hak atas tanah. Ciri pokok sistem positif adalah bahwa pendaftaran tanah/ pendaftaran hak atas tanah adalah menjamin dengan sempurna bahwa nama yang terdaftar dalam buku tanah adalah tidak dapat dibantah, walaupun ia ternyata bukanlah pemilik yang berhak atas tanah yang bersangkutan. Kebaikan dari sistem positif adalah: (1) Adanya kepastian dari buku tanah; (2) Peranan aktif dari pejabat balik nama tanah; dan (3) Mekanisme kerja dalam penerbitan sertifikat tanah mudah dimengerti orang awam. Sedangkan kelemahan dari sistem positif adalah: (a) Peranan aktif pejabat baik nama tanah akan memakan waktu yang lama. Pemilik yang sebenarnya berhak atas tanah akan kehilangan haknya oleh karena kepastian dari buku tanah itu sendiri; (b) Wewenang pengadilan diletakkan dalam wewenang administratif.

Kedua, sistem Publikasi Negatif. Menurut sistem publikasi negatif, segala apa yang tercantum di dalam sertifikat tanah dianggap benar sampai dapat dibuktikan suatu keadaan yang sebaliknya (tidak benar) di muka Pengadilan. Ciri pokok sistim publikasi negatif, adalah bahwa pendaftaran tanah/ pendaftaran hak atas tanah tidaklah menjamin bahwa namanama yang terdaftar dalam buku tanah tidak dapat untuk dibantah jika nama yang terdaftar bukanlah pemilik sebenarnya. Hak dari nama yang terdaftar ditentukan oleh hak dari pemberi hak sebelumnya. Ciri lainnya adalah bahwa pejabat balik nama tanah berperan pasif, artinya pejabat yang bersangkutan tidak berkewajiban untuk menyelidiki kebenaran dari surat yang diserahkan kepadanya. Aspek kebaikan dari sistem publikasi negative adalah adanya perlindungan kepada pemegang hak sejati. Sedangkan kelemahan dari sistem publikasi negatif: (1) Peranan pasif pejabat balik nama tanah yang menyebabkan tumpang tindihnya sertifikat tanah. (2) Mekanismekerja dalam proses penerbitan sertifikat tanah sedemikian rupa sehingga kurang dimengerti oleh awam. ${ }^{21}$

Sistem publikasi yang digunakan Peraturan Dasar Pokok-Pokok Agraria (UUPA) adalah sistem negatif yang mengandung unsur positif. UUPA tidak menggunakan sistim publikasi positif yang murni karena menghasilkan surat-surat tanda bukti hak yang berlaku sebagai alat pembuktian yang kuat dan tidak menggunakan sistem publikasi negatif yang murni karena kegiatan pemeliharaan dan penerbitan sertifikat hak dilakukan secara seksama agar data yang disajikan sejauh mungkin dapat dipertanggungjawabkan kebenarannya. ${ }^{22}$ Sistem publikasi yang dipergunakan oleh Peraturan Dasar Pokok-Pokok Agraria (UUPA disebut dengan sistem negatif yang bertendens positif.

Pengertian bertendens positif adalah adanya peran aktif pelaksana pendaftaran, yaitu antara lain: (1) Adanya penyelidikan bidang tanah secara teliti; (2) Pengumuman selama 3 (tiga) bulan untuk pendaftaran tanah tersebut. Pengumuman ini dimaksudkan untuk memberikan kesempatan kepada pihak lain untuk mengajukan keberatan, jika merasa hak tersebut merugikan dirinya. Adapun ciri-ciri sistem negatif bertendens positif adalah: (1) Nama pemilik tanah yang tercantum dalam daftar buku tanah adalah benar dan dilindungi oleh hukum dan sertifikat merupakan tanda bukti hak yang tertinggi; (2) Setiap peristiwa balik nama melalui prosedur dan penelitian yang seksama dan memenuhi syarat-syarat keterbukaan untuk umum; (3) Setiap bidang tanah batas-batasnya diukur dan digambarkan dalam peta pendaftaran dengan skala 1: 1000, ukuran mana memungkinkan untuk meneliti kembali batas-batas persil bila dikemudian hari terdapat sengketa-sengketa batas; (4) Pemilik tanah yang tercantum dalam buku tanah dan sertifikat masih dapat diganggu gugat melalui Pengadilan Negeri dan sertifikat masih dapat dicabut melalui Pengadilan Negeri atau

\footnotetext{
${ }^{21}$ Mudjiono, Politik Agraria Nasional-Hubungan Manusia Dengan Tanah Yang Berdasarkan Pancasila, (Yogyakarta: GAMA University Press, 1999), h. 30-34

${ }_{22}$ Boedi Harsono, Hukum Agraria Indonesia-Sejarah Pembentukan.., h. 481.
} 
oleh Direktorat Jenderal Agraria atas nama Menteri Dalam Negeri; (5) Pemerintah tidak menyediakan dana untuk pembayaran ganti rugi kepada masyarakat karena kesalahan administrasi pendaftaran tanah, melainkan masyarakat yang merasa dirugikan dapat menuntut melalui Pengadilan Negeri.

\section{Penerbitan Sertifikat}

MenurutPasal 1 ayat(20) Peraturan Pemerintah Nomor 24. Tahun 1997 tentang Pendaftaran Tanah, Sertifikat adalah surat tanda bukti hak sebagaimana dimaksud dalam Pasal 19 ayat (2) huruf c UUPA untuk hak atas tanah, hak pengelolaan, tanah wakaf, hak milik atas satuan rumah susun dan hak tanggungan yang masing-masing sudah dibukukan dalam buku tanah yang bersangkutan. ${ }^{23}$ Selanjutnya Pasal 32 (1) Peraturan Pemerintah Nomor 24. Tahun 1997 tentang Pendaftaran Tanah, disebutkan bahwa sertipikat merupakan surat tanda bukti hak yang berlaku sebagai alat pembuktian yang kuat mengenai data fisik dan data yuridis yang termuat di dalamnya, sepanjang data fisik dan data yuridis tersebut sesuai dengan data yang ada dalam surat ukur dan buku tanah hak yang bersangkutan. ${ }^{24}$

Dari pengertian di atas, maka sertifikat secara yuridis adalah merupakan bukti otentik atas hak-hak atas tanah yang dimiliki oleh pemegang hak tersebut sehingga ia secara yuridis pula memiliki kepastian haknya dan terlindungi haknya. Karenanya untuk mendapatkan sertifikat, tahap-tahap yang harus dilalui adalah: Tahap pertama, bila tanah berasal dari warisan, para ahli waris, yaitu mereka yang menerima warisan tanah, baik tanah bekas hak milik adat ataupun hak-hak yang lain, harus melengkapi syarat-syarat: (1) Surat tanda bukti hak atas tanah, yang berupa

${ }^{23}$ Lihat Pasal 1 ayat (20) Peraturan Pemerintah Nomor 24. Tahun 1997 tentang Pendaftaran Tanah. Adapun bunyi utuh Pasal 19 ayat (2) huruf C UUPA adalah " Pendaftaran tersebut dalam ayat (1) pasal ini meliputi: a. pengukuran perpetaan dan pembukuan tanah; b. pendaftaran hak-hak atas tanah dan peralihan hak-hak tersebut; c. pemberian surat-surat tanda bukti hak, yang berlaku sebagai alat pembuktian yang kuat.

${ }^{24}$ Lihat Pasal 32 ayat (1) Peraturan Pemerintah Nomor 24. Tahun 1997 tentang Pendaftaran Tanah. sertifikat hak tanah yang bersangkutan; (2) Bila tanah yang bersangkutan belum pernah disertifikatkan, maka disertakan surat tanda bukti hak atas tanah yang lainnya, seperti Surat Pajak hasil bumi/ petuk D lama / verponding lama Indonesia dan segel-segel lama atau Surat Keputusan penegasan/ pemberian hak dari instansi yang berwenang; (2) Surat Keputusan Kepala Desa yang dikuatkan Camat yang membenarkan surat tanda bukti hak tersebut; (3) Surat keterangan waris dari instansi yang berwenang; (4) Surat pernyataan tentang jumlah tanah yang telah dimiliki; (5) Kartu Izin Tinggal Sementara (untuk orang asin); (6) Keterangan pelunasan pajak tanah sampai meninggalnya pewaris; (7) Izin peralihan hak, jika hal ini diisyaratkan.

Para pemilik tanah, yaitu mereka yang mempunyai tanah berasal dari jual beli, hibah, lelang, konversi hak dan lain-lain sebagainya, diharuskan melengkapi diri dengan persyaratan yang serupa. Bila tanah berasal dari jual beli, harus melengkapi syarat-syarat: (1) Akta jual beli yang dibuat oleh dan dihadapan PPAT; (2) Sertifikat hak tanah yang bersangkutan; (3) Bila tanahnya belum pernah disertifikatkan, maka harus diserahkan bukti atas tanah lainnya, seperti surat pajak atas hasil bumi / petuk D lama / perponding lama atau Surat keputusan penegasan / pemberi hak dari instansi yang berwenang; (4) Surat Keputusan Kepala Desa yang dikuatkan Camat yang membenarkan surat tanda bukti hak tersebut; (5) Surat pernyataan jumlah tanah yang telah dimiliki; (6) Turunan surat keterangan warga negara Indonesia yang disahkan oleh pejabat yang berwenang; dan (7) Izin peralihan hak, jika hal ini diisyaratkan.

Bila tanahnya berasal dari hibah, syarat-syarat tersebut adalah: (1) Akta hibah yang dibuat oleh dan dihadapan PPAT; (2) Sertifikat hak atas tanah yang bersangkutan. Sedangkan bila tanahnya belum pernah disertifikatkan, maka harus diserahkan bukti atas tanah lainnya, seperti: (1) Surat pajak hasil bumi/ petuk D lama/ perponding lama atau Surat keputusan penegasan/ pemberi hak dari instansi yang berwenang; (2) Surat Keputusan Kepala Desa 
yang dikuatkan Camat yang membenarkan surat tanda bukti hak tersebut; (3) Surat Pernyataan tentang jumlah tanah yang telah dimiliki; dan (4) Turunan surat keterangan warga negara Indonesia yang disahkan oleh pejabat yang berwenang. Adapun untuk tanah yang berasal dari lelang, maka syarat yang harus dipenuhi adalah: (a) Kutipan otentik berita acara lelang yang dibuat oleh Kantor Lelang; (b) Sertifikat hak tanah yang bersangkutan atau tanda bukti hak atas tanah lainnya yang telah diketahui oleh Kepala Desa yang dikuatkan oleh Camat; (c) Surat pernyataan tentang jumlah tanah yang telah dimilikinya; (d) Keterangan pelunasan / bukti lunas pajak tanah yang bersangkutan; (e) Turunan surat keterangan warga negara Indonesia yang telah disahkan oleh pejabat yang berwenang; (f) Surat Keterangan Pendaftaran Tanah (SKPT) yang diminta sebelum lelang dilakukan.

Bila tanahnya berasal dari konversi tanah adat, syarat-syarat yang harus dipenuhi bagi daerah yang sebelum tanggal 24 September 1960 sudah dipungut pajak, adalah: (a) Surat pajak hasil bumi/ petuk D lama/ perponding Indonesia dan segel-segel lama; (b) Keputusan penegasan/ pemberian hak dari instansi yang berwenang; (c) Surat asli jual beli, hibah, tukar menukar dan sebagainya; (d) Surat Keterangan Kepala Desa yang dikuatkan oleh Camat yang membenarkan keterangan- keterangan tentang tanah yang bersangkutan; (e) Surat Keterangan yang berisi bahwa tanah tersebut tidak berada dalam sengketa dan tidak dijadikan tanggungan utang serta sejak kapan dimiliki. Sedangkan bagi daerah yang sebelum 24 September 1960 belum dipungut pajak maka persyaratan yang harus dipenuhi adalah: (a) Keputusan penegasan/ pemberian hak tanah yang dibuat oleh instansi yang berwenang; (b) Surat asli jual beli, tukar menukar, hibah, yang diketahui atau dibuat atau disaksikan oleh Kepala Desa/ pejabat yang setingkat; (c) Surat Keterangan Kepala Desa yang dikuatkan oleh Camat yang membenarkan isi keterangan-keterangaan tentang tanah yang bersangkutan; (d) Surat pernyataan yang berisi bahwa tanah tersebut tidak berada dalam sengketa.
Bila tanahnya berasal dari konversi tanah hak barat, syarat-syaratnya: (a) Grosse akta; (b) Surat ukur; (c) Turunan surat keterangan warga negara yang disahkan oleh pejabat yang berwenang; (d) Kuasa konversi, bila pengkonversian itu dikuasakan pada seseorang; (e) Surat pernyataan pemilik yang berisi bahwa tanah tersebut tidak berada dalam sengketa, tidak dijadikan tanggungan hutang, sejak kapan dimiliki dan belum pernah dialihkan atau diberikan dengan sesuatu hak kepada pihak lain.

Tahap kedua, Setelah semua persyaratan dipenuhi, selanjutnya diserahkan pada kantor pertanahan Kabupaten / Kota setempat. Kegiatan selajutnya dilakukan oleh seksi pendaftaran tanah meliputi pengukuran, pemetakan, dan pendaftaran haknya. Tahap ketiga, adalah tahap terakhir ketika semua hak-hak atas tanah yang telah dibukukan dibuatkan salinan dari buku tanah yang bersangkutan. Salinan buku tanah dan surat ukurnya atau gambar situasi, kemudian dijahit menjadi satu dengan diberi kertas sampul yang bentuknya telah ditetapkan oleh Menteri Dalam Negeri cq. Dirjen Agraria ${ }^{25}$ yang sekarang ditingkatkan menjadi Lembaga Pemerintah Non Departemen dengan nama Badan Pertanahan Nasional (Keputusan Presiden Nomor 26 Tahun 198 ).

\section{Kesimpulan}

Berdasarkan uraian dan analisa yang telah penulis lakukan pada bagian terdahulu, maka maka dapat disimpulkan bahwa implementasi Penguatan Hak Atas Tanah Rakyat Melalui Akselerasi Program PRONA di Kantor Pertanahan Kabupaten dan Kota pada dasarnya sudah dilakukan secara rutin tiap tahun. Adapun tahapan schedule imlementatifnya melalui proses, persiapan, koordinasi/penetapan peserta PRONA, penyuluhan, pengukuran, pengumpulan data, pengumuman, penetapan Hak Atas Tanah, pembukuan hak, penerbitan sertipikat, dan penyerahan sertifikat. Bahkan secara yuridis Kantor Pertanahan Kabupaten dan Kota telah melaksanakan amanat UU Nomor 5 Tahun 1960 tentang Peraturan Dasar

\footnotetext{
${ }^{25}$ Mudjiono, Politik Agraria Nasional .., h. 89-98
} 
Pokok-Pokok Agraria, Peraturan Kepala Badan Pertanahan Nasional Republik Indonesia Nomor 6 Tahun 2006 tentang Rencana Strategis Badan Pertanahan Nasional Republik Indonesia

\section{DAFTAR PUSTAKA}

Ali, Achmad, Menguak Tabir Hukum (Suatu Kajian Filosofis dan Sosiologis), Jakarta: Gunung Agung, 2002.

Badrulzaman, Mariam Darus, Mencari Sistem Hukum Benda Nasional, Bandung: Alumni, 1997.

Basuki, Sunaryo, Pendaftaran Tanah Berdasarkan Pasal 19 UUPA Jo. PP No. 24 Tahun 1997, Jakarta: tp, 1998.

Buku 1 Rencana Strategis BPN-RI Tahun 2007-2009

Dalimunthe, Chdidjah, Pelaksanaan Landreform di Indonesia dan Permasalahannya, Medan: FH USU Press, 2000.

Sutedi, Adrian, Peralihan Hak Atas Tanah dan Pendaftarannya, Jakarta: Sinar Grafika, 2007.

Effendi, Bachtiar, Pendaftaran Tanah di Indonesia dan Peraturan Pelaksanaannya, Bandung: Alumni, 1993.

Gautama, Sudargo, , Tafsiran Undang-Undang Poko Agraria, Bandung: Citra Aditya Bhakti,1993.

Harsono, Boedi, Hukum Agraria Indonesia, Himpunan Peraturan- Peraturan Hukum Tanah, Jakarta: Djambatan, 2006.

Harsono, Boedi,, Hukum Agraria Indonesia, Sejarah Pembentukan Undang-Undang Pokok Agraria, Isi dan Pelaksanaannya Jilid I, Hukum Tanah Nasional, Edisi Revisi Jakarta: Djambatan, 1999.

Harsono, Boedi,, Jaminan Kepastian Hukum di Bidang Pertanahan, Kasus-Kasus Pengadaan Tanah Dalam Putusan Pengadilan (Suatu Tinjauan Yuridis), Mahkamah Agung Republik Indonesia, Jakarta:tp, 1998.

Handoko, Amin, Peranan Kantor Pertanahan Kabupaten Demak Dalam Upaya Meningkatkan Pendaftaran Hak Atas Tanah, Semarang: Tesis PPs Kenotarian UNDIP, 2008.

Herman Hermit, Cara Memperoleh Sertipikat Tanah Hak Milik, Tanah Negara dan Tanah
(Renstra BPN RI) Tahun 2007-2009, serta Keputusan Menteri Dalam Negeri Nomor 189 Tahun 1981 tentang Proyek Operasi Nasional Agraria (PRONA).

Pemda, Teori dan Praktek Pendaftaran Tanah di Indonesia, Bandung: Mandar Maju, 2004.

Idham, Konsolidasi Tanah Perkotaan Dalam Perspektif Otonomi Daerah, Bandung: Alumni, 2004.

Lubis, Muhammad Yamin dan Abdul Rahim Lubis, Hukum Pendaftaran Tanah, Bandung: Mandar Maju, 2008.

Mahja, Djuhad, Kewenangan Otonomi Daerah Dalam Bidang Pertanahan Di Kabupaten Kendal, Semarang: Tesis PPs Kenotarian UNDIP, 2008.

Maria S.W, Sumardjono, Kebijakan Pertanahan Antara Regulasi dan Implementasi, Edisi Revisi, Jakarta: Kompas, 2007.

Mertokusumo, Sudikno, Mengenal Hukum Suatu Pengantar, Yogyakarta: Liberty, 2003.

N.D., Mukti Fajar dan Yulianto Achmad, Dualisme Penelitian Hukum Normatif dan Empiris, Yogyakarta: Putaka Pelajar, 2010

Paranginangin, Efendi, 401 Pertanyaan dan Jawaban tentang Hukum Agraria, Jakarta: Raja Wali Press, 1991.

Parlindungan, A.P., Komentar Atas UndangUndang Pokok Agraria, Bandung: Mandar Maju, 2002,

Parlindungan, A.P., Pendaftaran Tanah di Indonesia, Bandung: Mandar Maju, 1999.

Prakoso, Djoko dan Budiman Adi Purwanto, Eksistensi Prona Sebagai Pelaksanaan Mekanisme Fungsi Agraria, Jakarta: Ghalia Indonesia, 1985.

Priyatnadi, I Made Budi, Ketaatan Masyarakat Dalam Pendaftaran Tanah Untuk Pertama Kali Secara Sporadik Di Kecamatan Batulayar Kabupaten Lombok Barat Kendal, Semarang: Tesis PPs Kenotarian UNDIP, 2008.

Saleh, Wantjik, Hak Anda Atas Tanah, Jakarta: Ghalia Indonesia, 1987.

Soekanto, Soerjono, Faktor-Faktor yang 
Mempengaruhi Penegakan Hukum, Jakarta: Raja Grafindo Persada, 1993.

Soekanto, Soerjono, Pengantar Penelitian Hukum, Jakarta: UI Press, 1986.

Soekanto, Soerjono, dan Sri Mamudji, Penelitian Hukum Normatif Suatu Tinjauan Singkat, Jakarta: Raja Grafindo Persada, 2003.

Supriadi, Hukum Agraria, Jakarta: Sinar Grafika, 2006.

Wahit, Muchtar, Memaknai Kepastian Hukum HakMilik Atas Tanah, Suatu Analisa dengan Pendekatan Terpadu Secara Normatif dan Sosiologis, Jakarta: Republika, 2008.

A. Sri Sabarini, Januari 1989, Struktur Pemilikan Tanah, Masalah dan Prospek, Pro Justitia, Nomor 1 Tahun VII, Bandung.

Bhumi Bhakti, 2006, Pertanahan Perekat Kesatuan Republik Indonesia, Badan Pertanahan Nasional, Jakarta;

Undang-Undang Dasar Republik Indonesia Tahun 1945, Pustaka Setia, Bandung, Tanpa Tahun;

Undang-Undang Republik Indonesia Nomor 5 Tahun 1960 tentang Peraturan Dasar Pokok-Pokok Agraria;

Undang-Undang Nomor 25 Tahun 2004, tentang Sistem Perencanaan Pembangunan Nasional (SPPN);

Peraturan Presiden Republik Indonesia Nomor 7 Tahun 2005 tentang Rencana Pembangunan Jangka Menengah Nasional (RPJMN), Tahun 2004-2009;

Peraturan Pemerintah Nomor 40 Tahun 1996 tentang Hak Guna Usaha, Hak Guna Bangunan dan Hak Pakai atas Tanah.

Peraturan Pemerintah Republik Indonesia Nomor 24 Tahun 1997 tentang Pendaftaran Tanah;

Peraturan Pemerintah Republik Indonesia Nomor 37 Tahun 1998 tentang Peraturan Jabatan Pejabat Pembuat Akta Tanah;

Peraturan Pemerintah Nomor 10 Tahun 2006 tentang Badan Pentanahan Nasional;

Peraturan Menteri Agraria/Kepala Badan Pertanahan Nasional Nomor 3 Tahun 1997 tentang Ketentuan Pelaksanaan Peraturan Pemerintah Nomor 24 Tahun 1997 tentang Pendaftaran Tanah;
Peraturan Kepala Badan Pertanahan Nasional Republik Indonesia Nomor 3 Tahun 2006 tentang Organisasi dan Tata Kerja Badan Pertanahan Nasiona Republik Indonesia;

Peraturan Kepala Badan Pertanahan Nasional Republik Indonesia Nomor 4 Tahun 2006 tentang Organisasi dan Tata Kerja Kantor Wilayah BPN Propinsi dan Kantor Pertanahan Kabupaten/Kota.

Peraturan Kepala Badan Pertanahan Nasional Republik Indonesia Nomor 6 Tahun 2008 tentang Penyederhanaan dan Percepatan Standar Prosedur Operasi Pengaturan dan Pelayanan Pendaftaran Untuk Jenis Pelayanan Pertanahan Tertentu.

Peraturan Kepala Badan Pertanahan Nasional Republik Indonesia Nomor 13 Tahun 2010 tentang Jenis dan Tarif Atas Jenis Penerimaan Negara Bukan Pajak Yang Berlaku Pada Badan Pertanahan Nasional.

Keputusan Menteri Dalam Negeri Nomor 189 Tahun 1981 tentang Proyek Operasi Nasional Agraria (PRONA).

Peraturan Menteri Negara Agraria/Kepala Badan Pertanahan Nasional No. 3 tahun 1999 tentang Pelimpahan Kewenangan Pemberian dan Pembatalan Keputusan Pemberian Hak Atas Tanah Negara.

Peraturan Menteri Negara Agraria/Kepala Badan Pertanahan Nasional No. 9 tahun 1999 tentang Tata Cara Pemberian dan Pembatalan Hak Atas Tanah Negara dan Hak Pengelolaan.

Peraturan Kepala Badan Pertanahan Nasional Republik Indonesia Nomor 3 Tahun 2006 tentang Organisasi dan Tata Kerja Badan Pertanahan Nasional Republik Indonesia.

Peraturan Kepala Badan Pertanahan Nasional Republik Indonesia Nomor 6 Tahun 2006 tentang Rencana Strategis Badan Pertanahan Nasional Republik Indonesia (Renstra BPN-RI) Tahun 2007-2009.

Peraturan Kepala Badan Pertanahan Nasional Nomor 7 Tahun 2007 tentang Panitia Pemeriksaan Tanah. 